\title{
Výchova ke vztahu ke kulturně historickému dědictví a vzdělávání pro udržitelný rozvoj v ČR
}

\author{
Hana Havlůjová, Dušan Foltýn, Kateřina Charvátová \\ Envigogika 2012/VII/3- Recenzované články/ Reviewed Papers \\ Publikováno/Published 31 12. 2012
}

DOI: http://dx.doi.org/10.14712/18023061.78

\begin{abstract}
Abstrakt:
Příspěvek se zabývá otázkou, jak na českých základních a středních školách podporovat vzdělávání pro udržitelný rozvoj. Metodologicky vychází z konceptu výchovy ke vztahu ke kulturně historickému dědictví, jež umožňuje autenticky propojovat život ve škole s různými aspekty společenského dění mimo ni. Příspěvek představuje teoretická východiska konceptu i tři konkrétní př́klady jeho uplatnění v české školní praxi. Poukazuje také na zahraniční inspirace a paralely a zabývá se podněty, které vyplynuly z mezinárodního srovnání príkladů dobré praxe. Z nich napríklad vyplynulo, že obnova zodpovědného vztahu k místu a komunitě patří $v$ současné době mezi významnou společenskou potřebu $v$ celé Evropě. Zvláště pak rezonuje $v$ místech, kde byl v minulosti přirozený vztah ke kulturně historickému dědictví uměle narušen či násilně zpřetrhán. Paradoxně právě zde se však otevírá největší prostor pro pưsobení škol a citlivé využívání regionálního kulturně historického dědictví ku prospěchu žákư i místních komunit.
\end{abstract}

\section{Klíčová slova:}

Kulturně historické dědictví, výchova, vzdělávání pro udržitelný rozvoj

\begin{abstract}
:
A concept of heritage education that connects the 'inner' life of school with community life 'outside' school is discussed in this article. The theoretical background of the concept and three practical case studies from Czech schools are brought to the readers' attention in order to illustrate how education for sustainable development is supported in the Czech Republic. The article also reviews the various stimuli that emerged from the international comparison of good practice. For instance, the need to encourage a responsible relationship to the local landscape, nature and community seems to be a shared goal all over Europe nowadays. It resonates especially in the regions where the relationship to cultural heritage had been disrupted in the past. Paradoxically, the most neglected regions tend to offer the most extraordinary opportunities for school-based activities and a sensible use of the local heritage for the benefit of both pupils and local communities.
\end{abstract}

\section{Key words:}

Cultural heritage, education, education for sustainable development 
Uplatnění konceptu trvale udržitelného rozvoje světového společenství předpokládá kvalitativní a systémové změny $v$ různých oblastech lidské činnosti. ${ }^{1}$ Ve snaze přeorientovat lidské působení ve světě tak, aby bylo možné usilovat o zajištění zdravého, bezpečného a spravedlivého světa pro současné i budoucí generace, iniciovala Organizace spojených národů na počátku nového tisíciletí také program tzv. Dekády vzdělávání pro udržitelný rozvoj (2005-2015). Záměrem se stalo revidovat z dlouhodobého hlediska obsahy a metody vzdělávání a posílit všechny jejich klíčové aspekty, které povedou $\mathrm{k}$ udržitelnému rozvoji. ${ }^{2}$

Jak upozornila Tereza Vošahlíková, cílem revizí a změn nemá být ani znásobování učiva, ani zavádění nových předmětů do stávajících vzdělávacích programů, ale spíše nový náhled na smysl a cíle vzdělávání. Klíčem k úspěchu je podle ní vytváření pestrých vzdělávacích přiležitostí, které umožňují propojovat poznatky z různých oblastí a oborů v zájmu řešení aktuálních otázek a problémù, jež se dotýkají života ve škole i mimo ni (Vošahlíková 2011).

Příklady z domácí i zahraniční praxe ukazují, že zejména problematika ochrany životního prostředí nabízí takových vzdělávacích příležitostí nespočet (Clark 2008, Činčera 2007, Horká 2005, Sobel 2005, Palmer 2003, Sokanová - Lišková 2002, Máchal 2000, Hederer 1994). Metody aktivního učení, na nichž se zakládá také dlouholetý úspěch české environmentální výchovy, pak umožňují rozvíjet kompetence k udržitelnému jednánía zároveň naplňovat $v$ předepsaném rozsahu obecné i specifické cíle formálního vzdělávání (Vošahlíková 2011, Pastorová a kol. 2011a, 2011b, Hušková a kol. 2010, SEVER 2010, Daňková - Kulich - Toušková 2009).

V našem příspěvku se však zaměříme na prezentaci přístupů, které na první pohled čerpají z didaktiky biologie a environmentální výchovy jen minimálně nebo druhotně. Přesto, alespoň podle našich dosavadních poznatků a zkušeností, nabízejí způsoby, jak na českých základních a středních školách vzdělávání pro udržitelný rozvoj úspěšně podporovat (Foltýn a kol. 2008, Parkan a kol. 2008, Charvátová 2009, Havlůjová Lešnerová 2012). Výchova ke vztahu ke kulturně historickému dědictví, z níž metodologicky vycházíme, klade důraz na integraci poznání z celého spektra oborů, včetně humanitních, společenskovědních a estetických disciplín. Ústřední téma - komunitní péči o kulturně historické dědictví - pak chápe jako př́ležitost pro celostní a aktivní učení a možnost autenticky propojovat život ve škole s různými aspekty aktuálního společenského dění (Havlưjová - Lešnerová 2012: 30). ${ }^{3}$

V příspěvku představíme teoretická východiska výchovy ke vztahu ke kulturně historickému dědictví i konkrétní příklady jejího uplatnění v české školní praxi. Poukážeme také na zahraniční inspirace a paralely a budeme se zabývat podněty, které vyplynuly z mezinárodního srovnání příkladů dobré praxe.

\section{Teoretická východiska a zahraniční inspirace}

„Historické prostředí má potenciál stimulovat každého, bez ohledu na věk nebo socio-kulturní původ, aby rozvíjel svou tvořivost, rozumové schopnosti i představivost, aby se aktivněji a sebevědoměji zapojil do občanského života a aby zvyšoval své porozumění

\footnotetext{
${ }^{1}$ Blíže viz Our Common Future, Report of the World Commission on Environment and Development, World Commission on Environment and Development, 1987 [online] [cit. 2012-20-12] Dostupné z: http://www.un-documents.net/wced-ocf.htm.

2 Podrobněji viz Decade for Sustainable Development [online] [cit. 2012-20-12] Dostupné z:

http://www.desd.org/.

${ }^{3}$ Srovnej například Šilhánková a kol. 2011, Šilhánková a kol. 2010, Krebs 2005.
} 
místnímu, přírodnímu, regionálnímu, národnímu i globálnímu prostředí" (Attingham Trust, 2004: 9).

$\mathrm{K}$ citovanému závěru dospěli autoři závěrečné zprávy rozsáhlého výzkumu, který proběhl na počátku nového tisíciletí ve Velké Británii a $v$ Severním Irsku. Cílem výzkumu bylo empiricky doložit a souhrnně popsat př́ležitosti, které poskytuje pro celoživotní učení historické prostředí. Zpráva Opening doors: Learning in the historic environment pak shrnula rozmanitá stanoviska ze světa politiky, památkové péče i výchovy a vzdělávání. Vyjádřila mezioborový, konkrétními daty podložený konsensus, který se dodnes ve Spojeném království projevuje z hlediska jiných zemí nadstandardní spoluprací škol s pamětovými a památkovými institucemi. ${ }^{4}$

Na výsledky národního výzkumu navázal také britský pedagog Tim Copeland, když pro potřeby Rady Evropy zvažoval, jak rozvinout vzdělávací potenciál kulturně historického dědictví v oblasti výchovy k občanství a sociální soudržnosti (2006). Parafrázujeme-li výše uvedený závěr z výzkumné zprávy Opening doors, jeho otázka zněla: Jak umožnit dětem a mladým lidem, aby se prostřednictvím vzdělávacích činností $v$ historickém prostředí zapojili do občanského života a aby lépe porozuměli nejen hodnotám místního nebo národního, ale také evropského dědictví? Odpovědí se stal koncept, který autor popsal s pomocí trojrozměrného modelu jako výchovu o kulturním dědictví, skrze a pro kulturní dědictví (Obr. 1).

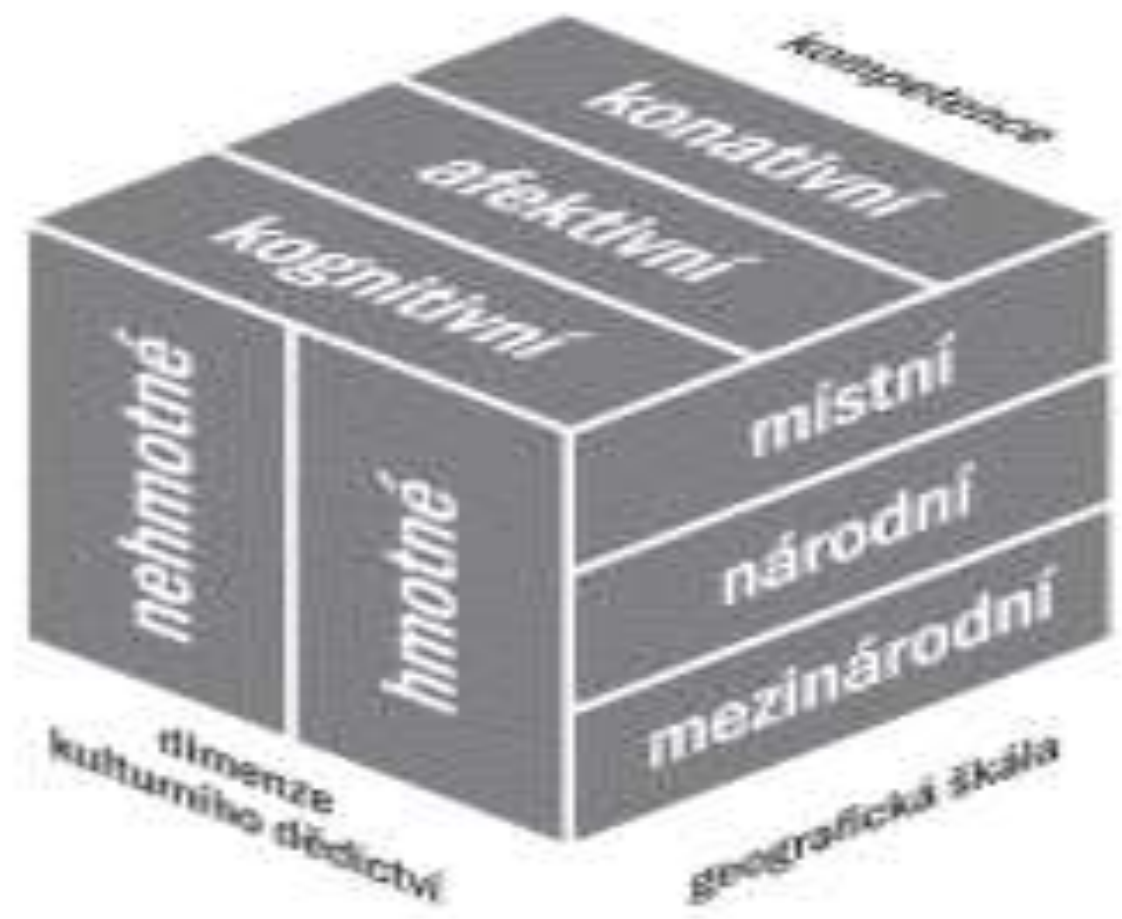

\footnotetext{
${ }^{4}$ Viz např́klad služby školám, které nabízí památkové organizace jako English Heritage, Royal Historical Palaces nebo National Trust. Vysoce rozvinutá je také spolupráce škol a pamětových institucí koordinovaná profesním sdružením Museums, Libraries and Archives, respektive Arts Council of Britain. Zpráva Opening doors je však v řadě ohledů relevantní i pro české prostředí. Navrhuje např́klad, aby došlo k takové úpravě rámcových vzdělávacích programů, jež by umožnila učinit historické prostředí základem prưřezové spolupráce, důležitou součástí výuky historie nebo výchovy $\mathrm{k}$ občanství. Navrženy jsou také změny učitelské př́ípravy, kupříkladu zvýšení podílu pamětových a památkových institucí na vzdělávání učitelů (Attingham Trust, 2004: 15).
} 
Obr. 1 Vzdělávací potenciál kulturního dědictví podle Tima Copelanda (2006: 17)

Model Tima Coplenda zohledňuje v první řadě hmotnou a nehmotnou povahu kulturního dědictví. Na geografické škále rozlišuje dědictví místní, národní a mezinárodní. Z hlediska pedagogického pak může podle autora kulturní dědictví jakéhokoli typu přispívat k rozvoji kognitivních, afektivních a konativních kompetencí.

Kompetenční rovina slouží Timu Coplendovi jako východisko pro charakteristiku tří základních přístupů, které Ize při využívání kulturního dědictví v oblasti formálního vzdělávání zvolit. Soustředí-li se podle něj vzdělávací aktivity převážně na rozvoj kognitivních kompetencí, kulturní dědictví se stává předmětem studia. At' už jako učitelé nebo jako žáci, učíme (se) o kulturním dědictví. Přednášky, komentované prohlídky, ale také exkurze nebo setkání s odborníky mají za cíl poučit posluchače o tom, co a proč je dobré uchovávat pro budoucnost (Copeland, 2006: 17).

Pokud se vzdělávací aktivity zaměři nejen na kognitivní, ale také na afektivní kompetence, mluví Tim Copeland o výchově skrze kulturní dědictví. v tomto ohledu má autor na mysli bud' výuku tradičních předmětů jako jsou matematika, zeměpis, angličtina nebo výtvarná výchova $v$ historickém prostředí, ${ }^{5}$ nebo možnosti, které kulturní dědictví nabízí pro rozvoj integrované tematické výuky a objevování mezipředmětových vztahů (Copeland, 2006: 17-18).

Jakmile je vzdělávání zacíleno také na rozvoj konativních, nebo chcete-li, akčních kompetencí, dochází podle Tima Copelanda k výchově pro kulturní dědictví. Tento př́stup pak žákům umožňuje, aby se různými aspekty kulturního dědictví zabývali ve smysluplném kontextu, a to nejen z hlediska vzdělávání, ale především z hlediska svého společenského uplatnění nebo rozvoje osobních zájmů. Nejčastější organizační formou výchovy pro kulturní dědictví jsou proto výchovně vzdělávací projekty, které cíleně aktivizují všechny složky kompetenční roviny (Copeland, 2006: 18).

Výchovu o kulturním dědictví, skrze a pro kulturní dědictví si podle Tima Copelanda nelze představit bez aktivizačních metod, projektové výuky, kooperativního učení, rozvoje sebeřízení a sebekázně, mezioborové spolupráce nebo mezinárodní kulturní výměny. Významnou roli v ní hraje partnerství učitelů, zástupců kulturních institucí, rodičů, ale také místních znalců (např. pamětníků, řemeslníků, umělců) a dobrodinců. Jak naznačuje víceúrovňové schéma, jedná se spíše o typ výchovy než o klasický školní předmět. Srovnatelné př́stupy pak autor nachází např́íklad v pojetí globální nebo environmentální výchovy (Copeland, 2006: 18-20). ${ }^{6}$

\section{Výchova ke vztahu ke kulturně historickému dědictví}

Použijeme-li českou pedagogickou terminologii, má výše popsaný koncept Tima Copelanda nejblíže $\mathrm{k}$ pojetí tzv. prưřezových témat. a právě tímto směrem se vydala skupina českých teoretiků, pedagogů a oborových didaktiků, kteří v letech 2006-2008 zkoumali a ověřovali, jak nejlépe zúročit výchovně vzdělávací potenciál kulturního dědictví $\checkmark$ našem prostředí.

\footnotetext{
${ }^{5}$ Srovnej např́klad Lockey - Walmsley 1999, Copeland 1993, Pownall - Hutson 1992, Copeland 1991.

${ }^{6}$ Srovnej také koncept heritage education postulovaný a propagovaný evropským sdružením HEREDUC. Blíže viz De Troyer, V., a kol. 2005.
} 
Projekt Metodika pro implementaci Výchovy ke vztahu ke kulturně historickému dědictví do školních vzdělávacích programü7 vycházel ze stále silněji pocitované společenské potřeby probudit $v$ žácích $v$ jejich formativním období zájem o prostředí, ve kterém žijí (obec, region), přivést je k uvědomění si jeho kulturních a historických hodnot a umožnit jim, aby k ochraně těchto hodnot a k péči o ně dovedli zaujmout aktivní postoj. $\mathrm{Na}$ základě projektových aktivit pak byl nejen teoreticky definován, ale především prakticky ověren koncept výchovy ke vztahu ke kulturně historickému dědictví, který po obsahové i formální stránce odpovídá záměrům školské reformy a kritériím průřezových témat. Zároveň od počátku propojuje rovinu pedagogickou s kvalitním meziodborovým zázemím a autentickými přesahy do společenskopolitické reality na lokální a regionální úrovni (Foltýn a kol. 2008, Parkan a kol. 2008, Charvátová 2009).

Na rozdíl od výše představeného Copelandova konceptu bylo pro potřeby české výchovně vzdělávací praxe kulturně historické dědictví definováno jako „prvky krajiny, hmotné a duchovní kultury, které jsou odkazem minulosti a je ve veřejném zájmu zachovat je pro budoucnost" (Foltýn a kol., 2008: 10).

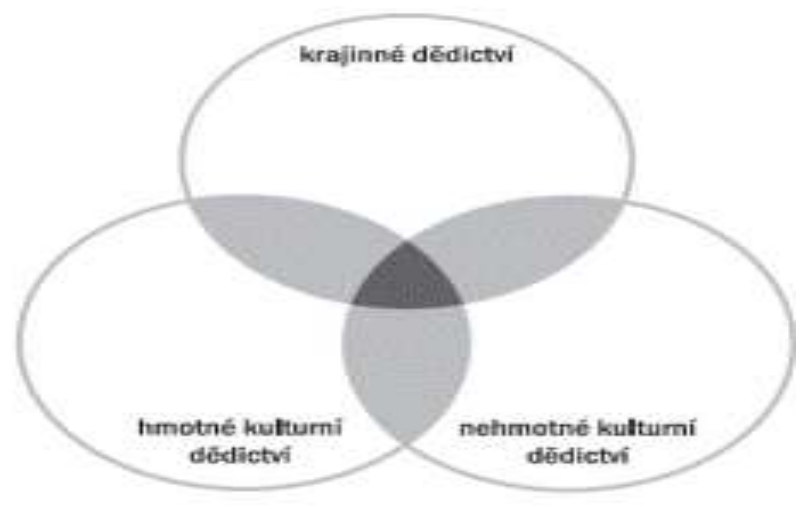

Obr. 2 Kulturně historické dědictví - tematické okruhy (Foltýn a kol., 2008: 11)

Jak naznačuje schéma, všechny tři složky kulturního dědictví se navzájem prolínají a mají řadu styčných bodů (Obr. 2). Vznikají tak také tři tematické okruhy, jež pokrývají celou škálu vědních oborů, z nichž je možné při výuce čerpat faktograficky i metodologicky. ${ }^{8}$ Pod pojem krajinné dědictví byly zahrnuty otázky vzájemného prolínání přírodních a kulturních vlivů v určitém místě, historické proměny kulturní krajiny, utváření estetické hodnoty krajiny, ochrany krajinného rázu i aktivní péče o krajinu. Hmotné kulturní dědictví označuje nemovité památky včetně dokladů lidového stavitelství či industriální architektury, historické i umělecké předměty, movité doklady o změnách

\footnotetext{
7 Projekt Metodika pro implementaci Výchovy ke vztahu ke kulturně historickému dědictví do školních vzdělávacích programů podpořený Evropským sociálním fondem v rámci operačního programu Rozvoj lidských zdrojů byl realizován v letech 2006-2008 na Katedře dějin a didaktiky dějepisu Pedagogické fakulty UK v Praze.

${ }^{8} \mathrm{~V}$ rámci projektu Metodika pro implementaci Výchovy ke vztahu ke kulturně historickému dědictví do školních vzdělávacích programů byl podrobně popsán vzdělávací potenciál archeologie, historie, dějin umění, etnologie, estetiky, humanitní environmentalistiky a výzkumu průmyslového dědictví. $\mathrm{Na}$ monografii Prameny paměti. Sedm kapitol o kulturně historickém dědictví pro potřeby výchovné praxe se podíleli D. Foltýn, K. Charvátová, P. Meduna, R. Schmelzová, V. Skálová, K. Stibral, J. Woitsch, J. Zahradníková a D. Zajoncová. Blíže viz Foltýn a kol. 2008.
} 
životního stylu. Pojem odkazuje také k souvisejícím otázkám památkové péče, sběratelství či muzejní ochrany artefaktů. Nehmotné kulturní dědictví shrnuje problematiku zachovávání historické paměti, znalostí a dovedností včetně jazyka a literatury, hudby a tanců, zvyků a tradic, kulinárních specialit či pomístních názvů (Foltýn a kol., 2008: 11).

Dưraz na veřejný zájem ve výše citované definici odkazuje ke skutečnosti, že v demokratické společnosti nejsou ochrana a zachování kulturních hodnot záležitostí individuálního rozhodování, ale rodí se ve společenské diskusi. ${ }^{9}$ Školní projekty, které z uvedené definice vycházejí, potom skýtají nejen prostor pro rozvoj specializace žáků, ale také pro zvyšování míry participace všech zúčastněných na rozhodování o kvalitě života místního společenství (Havlůjová, 2008: 14).

Záměrem výchovy ke vztahu ke kulturně historickému dědictví je proto umožnit žákům, aby si vytvářeli kladný vztah především k dědictví na úrovni regionu, ze kterého pocházejí nebo kam chodí do školy: „Právě zde totiž vznikají přímé osobní vazby k místu i lidem, právě zde se žáci mohou nejlépe podílet na účinné ochraně krajiny či pamětihodností, vyslovit se k rozhodnutím místních zastupitelských orgánů či se plnohodnotně zapojit do života místní komunity. Zakotvení v určitém místě pak slouží jako výchozí bod pro pochopení širších souvislostí ve smyslu sounáležitosti našeho a celosvětového kulturního dědictví" (Zahradníková, 2008: 8).

Podobně jako v př́padě Copelandovy výchovy pro kulturní dědictví jsou nejčastějším způsobem realizace výchovy ke vztahu ke kulturně historickému dědictví školní projekty, které prostřednictvím rozmanitých metod autentického učení aktivizují všechny klíčové kompetence stanovené rámcovými vzdělávacími programy. Jako jeden příklad za všechny uvádíme projekt Ve Štorchových stopách, který ve školním roce 2007-2008 realizovali se žáky šestých tříd učitelé ze dvou základních škol ve Vodňanech ve spolupráci se zdejším Městským muzeum a galerií. ${ }^{10}$

Jak název projektu napovídá, autoři se inspirovali dílem spisovatele a pedagoga Eduarda Štorcha. Výuku pravěku však obohatili nejen na základě četby jeho slavných děl, ale především „reformním" pedagogickým přístupem. Tak jako kdysi Eduard Štorch motivovali vodňanští učitelé žáky k poznávání historie prostřednictvím osobních zážitků, emocionálních kontaktů se stopami minulosti, jež žáci objevovali v blízkém historickém prostředí. Během terénních exkurzí do okolí Vodňan navštívili účastníci projektu místa bývalých sídel, pohřebišt' a svatyň pravěkých předků. v depozitáři muzea pak zkoumali staré předměty. Postupně se snažili zrekonstruovat zmizelý svět pravěkého Vodňanska podle poznatků odborné literatury i podle vlastních názorů (Parkan a kol. 2008: 119-120).

Podle pedagogů projekt skutečně „umožnil emocionální motivační prožitek, který žáky dobře ,naladil na další práci. Žáci pracovali s hmotnými archeologickými prameny, zaučovali se v práci s odbornou literaturou, vytvářeli svoje interpretace na základě pramenné základny a odborné literatury a učili se diskutovat o problémech a umět obhájit svůj názor" (Brom - Šmídová - Velková 2008: 120). Ve druhé části projektu pak žáci uvedené znalosti a dovednosti uplatnili při tvorbě tematických učebních pomůcek, které byly nejprve vystaveny $v$ muzeu a posléze předány $\mathrm{k}$ užívání místním základním školám, a dále při vzniku informační brožury Pravěkem Vodňanska, jež byla určena široké veřejnosti a turistům. Za zmínku jistě stojí i fakt, že v rámci školních terénních exkurzí se podařilo identifikovat dosud neznámou archeologickou lokalitu (Parkan a kol. 2008: 122127).

\footnotetext{
${ }^{9}$ Srovnej například Fairclough 2008, Holden 2006, Clark 2001, Ashworth; Graham; Tunbridge 2000

${ }^{10}$ Projekt vytvořili, realizovali a jako příklad dobré praxe zpracovali Zdeněk Brom (ZŠ Alešova, Vodňany), Dagmar Šmídová (ZS Bavorovská, Vodňany) a Jitka Velková (Městské muzeum a galerie Vodňany). Podrobně viz Parkan a kol. 2008: 118-128.
} 
Přihlédneme-li k prezentovanému př́íkladu, můžeme říci, že projekt Ve Štorchových stopách přispěl $v$ první řadě $\mathrm{k}$ rozvoji žákovských kompetencí $k$ učení. Intenzivně bylo rozvíjeno zejména poznání žáků ve vzdělávacích oblastech Člověk a společnost a Umění a kultura. Jak doložily mimo jiné žáky vytvořené učební pomůcky či informační brožury, žáci byli např́klad schopni charakterizovat život pravěkých sběračů a lovců, jejich materiální a duchovní kulturu, nebo uvést př́klady archeologických kultur na našem území. Interdisciplinární přístup však přispěl k rozvoji žáků i v dalších vzdělávacích oblastech jako například Jazyk a jazyková komunikace, Člověk a příroda, Člověk a zdraví nebo Informační a komunikační technologie. Zároveň bylo realizováno několik tematických okruhů z prưřezových témat Osobnostní a sociální výchova, Výchova k myšlení v evropských a globálních souvislostech a Mediální výchova (Parkan a kol. 2008: 8-9, 120-121).

Díky rozmanitým úkolům byla posilována kompetence $k$ řešení problémů, nebot' žáci byli vedeni ke zvládání zadaných rolí i odlišnému způsobu práce, než byli doposud zvyklí. Jak upozornili vyučující, jejich svěřenci na prvním stupni "téměř nikdy nepracovali v týmech a neovládali žádné strategie učení, kromě učení nazpamět" (Brom - Šmídová Velková 2008: 124). v průběhu projektu bylo proto třeba žáky teprve naučit, jak se učit, jak ",kriticky posuzovat informace, vyhledávat informace $z$ více zdrojů atd. Zároveň se žáci [...] učili zvládat práci v týmech, přijímat své role v týmu" (Brom - Šmídová - Velková 2008: 124).

Jsou-li žáci nuceni řešit zcela nové problémové situace a objevovat různé varianty jejich řešení, vzniká řada autentických př́ležitostí, kdy mohou rozvíjet své kompetence komunikativní (Zahradníková 2008: 9). Tak i v rámci projektu Ve Štorchových stopách žáci uplatňovali komunikační dovednosti v ústní i písemné podobě, učili se rozumět různým záznamům, obrazovým i zvukovým materiálům, využívali všech dostupných informačních a komunikačních technologií (Parkan a kol. 2008: 9, 121).

V oblasti kompetence sociální a personální poukazuje vodňanský projekt na formativní charakter výchovy ke vztahu ke kulturně historickému dědictví. Ze zpětných vazeb žáků i učitelů vyplynulo, že přispěl $k$ celkovému rozvoji osobností žáků v oblasti postojů a hodnot, stejně tak jako ke zdokonalení specifických žákových schopností a dovedností. Pomohl k utváření pozitivního vztahu žáků k sobě samým i ke zlepšení jejich chování vưči sobě navzájem (Parkan a kol. 2008: 9, 121). Účast na projektu žáky motivovala např́klad k samostatnému poznávání regionálních dějin (Parkan a kol. 2008: 127). Řešení společných úkolů přispělo ke zkvalitnění sociálních vazeb ve třídách i mezi vodňanskými školami navzájem (Brom - Šmídová - Velková 2008: 120, 124).

Partnerská spolupráce škol s Městským muzeem a galerií sehrála významnou roli v upevňování kompetence občanské. Jak již bylo uvedeno výše, vycházíme z přesvědčení, že úroveň uchování a dalšího zhodnocení kulturně historického dědictví v naší zemi je $\checkmark$ př́mé souvislosti s kvalitou fungování občanské společnosti. Výchovně vzdělávací aktivity proto vedly také žáky vodňanských škol k respektování a oceňování kulturně historického odkazu minulosti a aktivně je zapojovaly, právě prostřednictvím spolupráce s místními pamětóvými institucemi, do společenského dění v místě jejich života (Parkan a kol. 2008: 9, 122). Při plnění zadaných úkolů nebo při veřejných prezentacích si žáci navíc uvědomovali, že společnost sestává z lidí vybavených nejrůznějšími dispozicemi a možnostmi. Dobré občanské soužití tak bylo podporováno pěstováním vzájemné úcty mezi vrstevníky i např́íc generacemi (Parkan a kol. 2008: 9, 124).

Výchova ke vztahu ke kulturně historickému dědictví podporuje $v$ neposlední řadě také rozvoj pracovní kompetence. Projektový způsob výuky vede žáky $\mathrm{k}$ participaci na promýšlení, realizaci i vyhodnocování dílčích pracovních aktivit. Praktické činnosti učí žáky hospodárnosti, péči o zvolené materiály i nástroje. Získané zkušenosti a dovednosti mohou žáci využít jak při realizaci výstupů projektu (učební pomůcka, výstava, informační brožura), tak i při dalším vzdělávání. Vzhledem k provázání školních projektů s reálným životem Ize také předpokládat významný vliv žákovských zkušeností na volbu budoucího povolání a rozvoj individuálních profesních předpokladů (Zahradníková 2008:9). 
Didaktická analýza, byt́ jen jednoho pilotního školního projektu, dokládá, že také česká výchova ke vztahu ke kulturně historickému dědictví rozehrává celý výchovně vzdělávací rejstřík ukrytý podle Tima Copelanda v kulturním dědictví. ${ }^{11} \mathrm{Na}$ prríkladu projektu Ve Štorchových stopách jsme viděli, že projekt žáky vedl k tomu, aby se o zkoumaných artefaktech ${ }^{12}$ či archeologických lokalitách dozvídali nové informace. Kulturně historické dědictví, které se dochovalo na Vodňansku, využily školy jako ústřední téma badatelských i uměleckých činností žáků. Jejich prostřednictvím si pak žáci osvojovali relevantní dovednosti, učili se vyjadřovat své pocity i postoje. Projekt však zároveň vytvořil prostor, aby se všichni jeho účastníci aktivně zapojili do řešení aktuálních otázek, které byly s předmětem jejich zájmu spojeny. Vzhledem k tomu, že v muzeu neexistovala expozice věnovaná pravěku a ani ve školách nebyly k dispozici pomůcky se vztahem k prehistorii regionu, mohli vodňanští žáci, učitelé i muzejníci spojit své síly a vytvořit tematickou učební pomůcku pro základní školy, výstavu a informační materiál pro širokou veřejnost. Díky tomu se žáci zcela autenticky zapojili do péče o společné kulturní hodnoty (Parkan a kol. 2008: 118-128, Havlůjová, 2012a: 17-18).

\section{Péče o kulturně historické dědictví a vzdělávání pro udržitelný rozvoj}

V letech 2009-2012 navázala na výsledky projektu Metodika pro implementaci Výchovy ke vztahu ke kulturně historickému dědictví do školních vzdělávacích programů další práce obdobně složeného týmu, která se zaměřila na kulturní dědictví jako součást životního prostředí a hledala cesty, jak mohou školy prostřednictvím aktivní péče o kulturně historické dědictví přispívat k udržitelnému rozvoji místních komunit. Ve spolupráci s Brontosauřím ekocentrem Zelený klub byl realizován projektKulturně historické dědictví jako východisko pro rozvoj znalostí, schopností a dovedností žákü ve vzdělávání pro udržitelný rozvoj,13 přičemž dưraz byl kladen na maximální využití vzdělávacích příležitostí, které nabízí projektová výuka (Tomková - Kašová - Dvořáková 2009, Kratochvílová 2009, Tichý 2008), respektive školní projekty vytvořené a realizované ve spolupráci s místními pamětovými institucemi a dalšími regionálními partnery (neziskové organizace, místní samospráva). Na šestnácti místech v České republice díky tomu proběhly pilotní partnerské projekty zaměřené na poznávání, propagaci i ochranu místního kulturního dědictví. ${ }^{14}$ Osm nejzdařilejších projektů pak autoři a autorky zpracovali do podoby př́kladů dobré praxe (Foltýn - Havlůjová 2012a, Havlůjová - Lešnerová 2012: 97-186). Dva z nich nám nyní pomohou detailněji ilustrovat komplexní přístup k využití kulturně historického dědictví pro podporu vzdělávání pro udržitelný rozvoj.

Projekt Lesní rybníky byl realizován ve školním roce 2010-2011 v jihočeském Lišově. ${ }^{15}$ v rámci partnerské spolupráce mezi základní školou, místními spolky a př́slušnými odbory městského úřadu byl $v$ jeho rámci navržen a realizován první bod naučné stezky. Slovy autorky a hlavní koordinátorky projektu Jaroslavy Veberové: „Vzniklo tak zastavení u rybníka Utopený, který patři do historické soustavy lesních rybníků. Rybník

\footnotetext{
11 i další příklady dobré praxe však dokládají, že projekty výchovy ke vztahu ke kulturně historickému dědictví programově pěstují úctu ke krajinnému, hmotnému i nehmotnému kulturnímu dědictví a udržitelnou péči o ně. Blíže viz Parkan a kol. 2008: 80-135.

12 Srovnej Durbin; Morris; Wilkinson, 1990.

${ }^{13}$ Projekt Kulturně historické dědictví jako východisko pro rozvoj znalosti, schopnosti a dovednosti žáků ve vzdělávání pro udržitelný rozvoj byl podpořen Evropským sociálním fondem v rámci operačního programu Vzdělání pro konkurenceschopnost a realizován v letech 2009-2012. 14 Pilotní projekty proběhly ve školním roce 2010/2011 v Bečově nad Teplou, Brně, Českém Krumlově, Dolní Dobrouči, Doudlebách nad Orlicí, ve Dvoře Králové nad Labem, v Havířově-Bludovicích, Hodslavicích, Hranicích na Moravě, Chocni, Chomutově, Lišově, Ostravě-Svinově, Teplicích, Trmicích a ve Vodňanech. Dokumentace viz www.historickededictvi.com.

15 Projekt koncipovala, koordinovala a jako př́klad dobré praxe zpracovala Jaroslava Veberová ze ZŠ a MŠ Lišov. Podrobněji viz Havlůjová - Lešnerová (ed.) 2012: 171-186.
} 
s klasickou dubovou hrází je zaklíněn mezi okraj a vnitřek lesa zvaného Zadní Klíny a je sídlištěm volavek a divokých kachen. Bez nadsázky Ize říci, že je jedním z nejkrásnějších míst $v$ této oblasti, a je navíc opředen hrůzostrašnou pověstí o utopené svatbě" (Veberová 2012: 171).

Hlavním cílem projektu Lesní rybníky bylo probudit u žáků druhého stupně lišovské základní školy zájem o historii a současnost místní krajiny, umožnit jim, aby se aktivně zapojili do tvorby vznikající naučné stezky a propojili tak školní teoretické poznatky s praktickými činnostmi. Projekt také usiloval o posílení komunikace mezi žáky napříc ročníky a zlepšení jejich schopnosti pracovat ve skupině. Zaměřil se zároveň na prohloubení vztahu mezi školou a městskou komunitou. Do projektu se zapojily všechny ročníky druhého stupně $v$ rámci různých vyučovacích předmětů (např. český jazyk a literatura, výtvarná výchova, hudební výchova, př́rodopis, zeměpis a dějepis, literárně dramatická výchova, užité výtvarné činnosti a informatika). v závěru se do programu projektu zapojila celá škola, tj. 366 žáků (Havlůjová - Lešnerová 2012: 171-174).

Na projektu však spolupracovala také celá řada dospělých. Hlavní projektový tým tvořili zpočátku jen vyučující, kteří se podělili o zodpovědnost za jednotlivé cíle projektu, zpracovali tematické plány předmětů s přihlédnutím k projektovým činnostem a připravili motivační aktivity. Posléze, již společně se žáky, hledali a naplňovali cíle žákovských projektových skupin. Žáci tak přišli do přímého kontaktu se zástupci městského úřadu v Lišově, zaměstnanci Státního okresního archivu v Českých Budějovicích, představiteli lišovského rybářského svazu či mysliveckého sdružení. Hlavní projektové týmy seznamovaly s výsledky své práce průběžně i širší lišovskou veřejnost: spolužáky, rodiče, představitele města i pamětníky - seniory. Na besedách se žáci učili vést řízenou diskusi, předávat, ale i doplňovat si informace. Na výstavě, v rámci projektového večera či slavnostního průvodu představovali žáci výstupy svých uměleckých činností a interpretací místa. Námětem se stala krajina v okolí lesních rybníků a pověst o utopené svatbě (Havlůjová - Lešnerová 2012: 176-180).

„Pověst se stala námětem textu kramářské písně ( $v$ 6. ročníku) a na podobné pohádkové motivy tvořily děti scénář a dramatizaci příběhu při literárně dramatické výchově v 7. ročníku. v 8. a 9. ročníku vznikala přírodní lyrika s tématem rybníků a jihočeské krajiny. v hodinách výtvarné výchovy se staly rybníky, príroda, pověsti i historie nevyčerpatelným zdrojem inspirace, žáci vytvářeli krajinomalby a ilustrace k pověsti i k básním, malovali kulisy, tvořili kostýmy" (Veberová 2012: 178). Věcné informace i výtvarné práce byly zúročeny při tvorbě prvního zastavení naučné stezky u rybníka Utopený. Na hrázi byla umístěna žáky navržená tabule, která poskytuje návštěvníkům „informace o historii soustavy lesních rybníků, o přírodě v jejím okolí a orientační plánek, podle kterého mohou už nyní navštívit všechna místa celé budoucí naučné stezky" (Veberová 2012: 179).

Projekt Lišovské rybníky představuje z řady důvodů velmi zdařilý př́klad komunitní péče o místní kulturně historické dědictví: „Ukazuje, jak Ize přispívat nejen k utváření hlubšího vztahu k místu, ve kterém žáci žijí, ale také k rozvoji šetrných forem cestovního ruchu a obrodě zdravého lokálního patriotismu. v různých fázích projektu vstupovali žáci a pedagogové opakovaně do kontaktu sodborníky, rodáky i pamětníky, aby společně identifikovali místní př́rodní a kulturní zajímavosti, shromáždili data a připravili podklady pro několikanásobnou interpretaci rybníku Utopený, respektive celé soustavy Lesních rybníků. Komunitní setkání, happening, výstava i zastavení naučné stezky [...] zvýšily návštěvnost a popularitu místa. Zároveň však také podpořily místní výrobu a služby. Změny, které přinesla realizace projektu Lesní rybníky, se dotkly celé komunity" (Havlůjová - Lešnerová 2012: 186). ${ }^{16}$

${ }^{16}$ Srovnej například také Carter 2004, Lauermann 2010, Nadace Partnerství 2012. 
Z didaktického hlediska je třeba podtrhnout, že žáci se prostřednictvím projektu naučili mnoho nových znalostí a dovedností a $v$ rámci uměleckých výchov měli celou řadu příležitostí utvářet si k místnímu kulturně historickému dědictví citový vztah. Díky aktivní účasti na organizaci komunitních aktivit si také vyzkoušeli, nakolik mohou ovlivňovat veřejné mínění a utvářet své životní prostředí. S využitím výše osvětlené Copelandovy klasifikace tak můžeme říci, že projekt Lesní rybníky rozvíjel kognitivní, afektivní i konativní kompetence žáků a patři tak mezi př́klady výchovy pro kulturní dědictví.

Přihlédneme-li zároveň k aktuálnímu akčnímu plánu, který je součástí vládního opatření ke Strategii vzdělávání pro udržitelný rozvoj ČR pro roky 2011 a 2012, zjistíme, že lišovský školní projekt přispěl k naplňování jeho priorit minimálně ve třech oblastech (VUR 2011, 4-5). Podpořil zcela konkrétně rozvoj občanské participace a dobrovolnictví. Napomohl lišovským občanům všech generací k formování poučeného a pozitivního vztahu k místnímu kulturně historickému dědictví a přispěl ke snižování sociálního napětí v místní komunitě (Havlůjová - Lešnerová 2012: 186). Tentýž dopad, avšak v severomoravském regionu, můžeme doložit také u projektu Muchovice: Za krajinou a lidmi minulosti (Havlůjová - Lešnerová 2012: 143).

Projekt realizovaný ve školním roce 2010-2011 žáky a učiteli ze základní školy Frýdecká v Havířově-Bludovicích vznikal ve spolupráci se Společenským a ekologickým centrem Muchovice. ${ }^{17}$ Hlavní iniciátor a koordinátor projektu, učitel dějepisu, výtvarné výchovy a informatiky, Přemysl Vaňek k tomu uvádí: „Na základě znalosti práce občanského sdružení Beskydčan jsme společně s panem Leo Koštálem vymysleli prvotní návrh projektu [...]. V průběhu práce jsme upřesňovali finální podobu výstupů, spolupracovali jsme s učiteli zeměpisu a př́rodopisu, kteří se zúčastnili i některých terénních výzkumư" (Vaněk 2012: 138). Cílem projektu se stalo přiblížit žákům i dalším zájemcům způsoby života lidí na pasekářské samotě v minulosti a srovnat jejich tehdejší vztah ke krajině s dneškem (Havlưjová - Lešnerová 2012: 137).

Jak připomínají autoři knihy Beskydy: Stavby a život v nich (2011), život Beskyd se za posledních sto let výrazně proměnil. Není již zdaleka tak závislý na místních přírodních podmínkách a zdrojích, jako tomu bývalo v minulosti. Množství obyvatel, kvalita jejich života i celková hospodářská situace zde již dávno převažuje přirozenou reprodukční schopnost krajiny. Ba co víc, přinejmenším na poli zdejší stavební kultury mưžeme sledovat nejméně dvě protichưdné tendence. Chalupáři, turisté či rekreanti usilují o zachování či obnovu pưvodního rázu krajiny. Horalé, pro něž jsou Beskydy stále ještě trvalým domovem, prosazují spíše komfortní podobu a kvalitu bydlení. Málokdo se však podle Jiřího Langera pokusí uvedeným poměrům porozumět a zamyslet se nad nimi z hlediska budoucí udržitelnosti (Langer - Šmíra - Bryol 2011). Projekt Muchovice: Za krajinou a lidmi minulosti však takovou ambici měl.

Žáci společně s učiteli nejprve postupně zjištovali informace o historii samoty, jež se stala nejen předmětem jejich bádání, ale také terénní základnou pro jejich výpravy do okolí. Žáci rozdělení do skupin podle odborných zájmů navštívili Státní okresní archiv ve Frýdku-Místku, Zemský archiv v Opavě a Valašské muzeu v přírodě v Rožnově pod Radhoštěm. Své poznatky konzultovali s etnografem Jiřím Langerem, bohemistou Ostravské univerzity Jaroslavem Davidem nebo folkloristkou z Frýdlantu nad Ostravicí Františkou Pituchovou. Při exkurzi v př́rodní rezervaci Mazácký Grůnik je provázel nedávno zesnulý ekolog Leo Koštal, krajové odrůdy ovocných stromù a keřư a místní plemena dobytka představili žákům pracovníci společnosti Gengel, o. p. s., a chovatel krajové ovce Valašky Petr Šimeček ze Starých Hamrů. Informace, zkušenosti i zážitky žáci následně zpracovávali do podob přístupných spolužákům i dalším návštěvníkům farmy

17 Autorem a koordinátorem projektu, který zpracoval jako př́klad dobré praxe, je Přemysl Vaněk ze ZŠ a MŠ Frýdecká, Havířov-Bludovice. Podrobněji viz Havlưjová - Lešnerová (ed.) 2012: $137-143$. 
v Muchovicích. o tradičních technikách, které si žáci vyzkoušeli, vznikla například autorská instruktážní videa, jež dnes slouží jako pomůcka ve výtvarné výchově. Pro potřeby návštěvníků Muchovic pak žáci vytvořili tři informační letáky a funkční webové stránky, kde je možné si stáhnout zvukové soubory k naučné audiostezce. ${ }^{18}$ Jednotlivá zastavení audiostezky byla výtvarně zpracována a na začátku léta 2011 instalována v krajině (Havlůjová - Lešnerová 2012: 139-141).

Roční, soustavná, ale zároveň tvưrčím způsobem proměnlivá práce umožnila žákům i pedagogům, aby hodnoty beskydské krajiny, místního hmotného i nehmotného kulturní dědictví postupně objevovali, reflektovali a přijali za své. Dưraz byl kladen na přiměřenost úkolů a rozvoj vnitřní motivace žáků: „Před žáky nebyly kladeny žádné velké cíle, měli se pokusit získat pod vedením učitele veškeré informace o daném místě, vše zhodnotit a zpracovat do takové podoby, aby si druzí lidé mohli něco o tom, co jsme zjistili, přečíst, poslechnout, prohlédnout, naučit se. Naším přáním bylo probudit v žácích vztah k přírodě a ke kraji, kde žijí, nebo na získaných poznatcích a rozdílech (dříve a dnes) ukázat žákům cestu šetrného přístupu k přírodě a nutnost udržitelného rozvoje. Protože jenom práce děti k zájmu nemotivuje, nikomu jsme nebránili, aby si při pěti terénních výzkumech užil odpočinku, legrace i kamarádství" (Vaněk 2012: 138).

Lze bez nadsázky tvrdit, že tvưrčí přístup i cílená podpora vnitřní motivace žáků se zúročily nejen v kvalitě výstupů, ale celého projektu vůbec. Do terénních výzkumů a prací se postupně zapojilo čtyřicet žáků, na digitálním zpracování výstupů posléze participoval celý druhý stupeň, tj. 100 žáků. Tak jako i v př́padě dalších pilotních projektů se jako vhodný - a pro žáky zároveň atraktivní - nástroj interpretace kulturně historického dědictví ukázala být nová média (Havlůjová - Lešnerová 2012: 143). i tentokrát rozvíjeli žáci díky participaci na projektu své kognitivní, afektivní i konativní kompetence, učili se a zároveň přebírali zodpovědnost za uchování dědictví svého regionu.

Jak dokládají oba stručně představené příklady dobré praxe, také žáci v České republice mohou společně $s$ učiteli a zástupci partnerských institucí spoluvytvářet život své komunity a přispívat ke změnám ve svém okolí. v rámci školních projektů, které byly v našem prípadě založeny na principech výchovy ke vztahu ke kulturně historickému dědictví, měli děti i dospělí příležitost aktivně se podílet na utváření kvality svého života a prostředí. Z př́kladů je také zřejmé, že spolupráce školy s mimoškolním prostředím zároveň aktivizovala neformální a informální učení všech zúčastněných. Ke změnám ve smyslu udržitelnosti místních komunit, zejména $v$ oblasti celoživotního učení a péče o kulturní dědictví, tak docházelo $v$ bezprostřední souvislosti $s$ autentickým průběhem těchto projektů.

\section{Závěr}

Soudě podle relevantních domácích i zahraničních zdrojů, můžeme kompetence k udržitelnému jednání rozčlenit do tří základních skupin (Kindlmannová - Vošahlíková 2010). První skupinu představují etické principy udržitelného jednání jako schopnost jednat zodpovědně, uplatnit emoční inteligenci, respektovat sebe a své okolí, jednat spravedlivě. Druhá skupina kompetencí zdưrazňuje vzájemné propojování, sítování, neboli retinitu ( $z$ lat., rete = sít). Reprezentují ji např́klad celostní a systémové myšlení, schopnost vidět souvislosti mezi různými obory, spolupracovat s druhými, kriticky myslet a vnímat rozmanitost. Poslední skupinu kompetencí tvoří schopnosti a dovednosti přispívající $k$ motivaci pro budoucnost, například schopnost být iniciativní, chápat učení jako celoživotní proces, předvídat následky jednání, být kreativní, hledat nová řešení, znát a používat nové technologie, upřednostňovat udržitelnou spotřebu (Vošahlíková 2011).

${ }^{18}$ Aktuální umístění viz Muchovice - za krajinou a lidmi minulosti [online] dostupné z: http://zsfrydecka.paskov.cz/szopja/?id=nabidka [2.prosince 2012] 
Jak dokládají příklady dobré praxe prezentované výše, projekty výchovy ke vztahu ke kulturně historickému dědictví podporují osvojování etických principů udržitelného jednání, retinitu i motivaci pro budoucnost u dětí i dospělých. Přispívají tak nejen k naplňování cílů vzdělávání pro udržitelný rozvoj, ale svým charakterem pomáhají zároveň integrovat principy a hodnoty udržitelnosti do rưzných oblastí života místních komunit. Pilotní projekty prokázaly, že školy mohou žáky skutečně vést $k$ zodpovědnému vztahu k rodnému místu, at' již cestou poznávání historie a kulturního odkazu minulosti, nebo skrze podíl na uchovávání a rozvíjení místních tradic. Zpětné vazby žáků naznačují, že řada zástupců nejmladší generace je ke kulturním hodnotám vnímavá a dokáže si uvědomovat jejich hodnotu nejen pro každodenní život obcí a měst, ale také pro jejich budoucnost.

Například žákyně sedmé třídy ze základní školy Husova v Brně, která se zúčastnila projektu Brno: Cesta za poznáním města, ve své reflexi projektu uvedla: „Město Brno mýma očima [...] není pouze město. Je to spousta věcí, mezi nimiž vyniká historie, i když spousta budov či věcí již zde nestojí - například z bran se zachovala pouze Měnínská ostatní nádherné památky tu přetrvávají. Je to volba nás lidí, co zde ponecháme, a co zbouráme jen třeba kvůli novému nákupnímu centru."19 Díky úspěšnosti projektu Mezi pražci mladějovské úzkokolejky, který je již více než pět let organizován ve spolupráci základní školy Kostelní náměstí v Moravské Třebové a Průmyslového muzea v Mladějově, se řada žáků, potažmo absolventů školy, do muzea vrací a zapojuje do činnosti zdejších dobrovolníkủ. 20 České př́klady proto mohou, zdá se, v mnoha ohledech sloužit jako inspirace pro školy, pamětové i památkové instituce také v zahraničí (Foltýn - Havlůjová 2012b). Přinejmenším v jedné oblasti však zatím český model školou iniciované komunitní péče o místní kulturně historické dědictví ve srovnání se zahraničními zkušenostmi zaostává.

Jedním z cílů projektu Kulturně historické dědictví jako východisko pro rozvoj znalostí, schopností a dovedností žáků ve vzdělávání pro udržitelný rozvoj bylo sdílení zkušeností, které v oblasti komunitní péče o lokální kulturní dědictví učinily školy, místní občanská sdružení i samosprávy, pamětové a památkové instituce nejen v České republice, ale také ve vybraných státech Evropské unie. ${ }^{21}$ Ze srovnání českých a zahraničních aktivit vyplynulo, že společnou péči o krajinu, hmotné i nehmotné kulturní dědictví Ize pokládat za nutný předpoklad kvalitního a stabilního rozvoje místních komunit napříč Evropou. Potvrdilo se také, že klíčem k dlouhodobé udržitelnosti je právě autentická, komunitní výchova (Foltýn - Havlůjová 2012a: 166).

Zahraniční i domácí př́klady dále poukázaly na skutečnost, že důležitým předpokladem úspěšnosti komunitních projektů bývá spolupráce pokud možno více zainteresovaných sektorů. Představeny byly různé modely kooperace škol, statní správy a místní samosprávy, pamět́ových a dalších odborných institucí a zájmových sdružení. Jak naznačuje Ideální model spolupráce při využití kulturního dědictví ve výchově a vzdělávání (Obr. 3), sestrojený na základě českých př́kladů dobré praxe, také komunitní péče o kulturní dědictví vychází ze širšího pojetí kolektivní odpovědnosti, kterou v zájmu udržitelného rozvoje v občanské společnosti sdílí různé zájmové skupiny (školy, nezisková

\footnotetext{
19 Viz Fiedlerová; Najbertová; Svátková 2011.

${ }^{20}$ Viz Novák 2012. Novák; Sýkora 2008. o aktuální situaci referovali autoři např́íklad v rámci mezinárodního symposia Kulturně historické dědictví a udržitelný rozvoj místních komunit (Praha, 25. březen 2011).

${ }^{21}$ Místem výměny zkušeností se stala mezinárodní konference uspořádaná na Pedagogické fakultě Univerzity Karlovy v Praze na jaře 2011. Výsledky viz Foltýn - Havlůjová (ed.) 2012a.
} 
sdružení, odborné instituce, místní politici) i jednotliví občané. Na rozdíl od zahraničí však $v$ české praxi zatím citelně schází větší zapojení podnikatelů a mecenášů. ${ }^{22}$

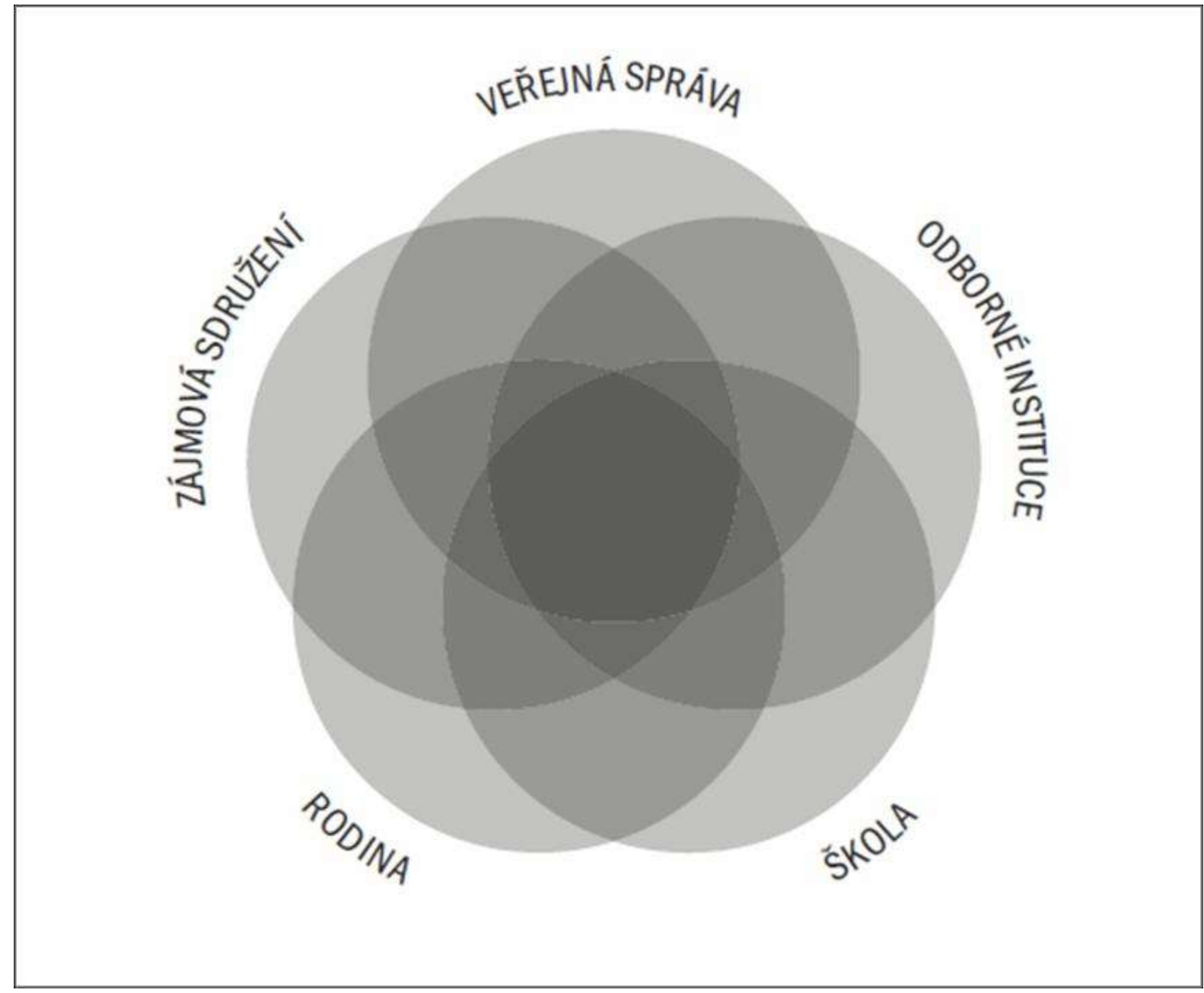

Obr. 3 Ideální model spolupráce při využití kulturního dědictví ve výchově a vzdělávání (Foltýn - Havlůjová, 2012a: 167)

I to je patrně jeden $z$ mnoha neblahých důsledků poválečného vývoje Československa, s nímž je nám dnes dáno se vyrovnávat. Připočtěme dopady poválečného vysídlení českých Němcủ, které zanechalo dosud nezhojené traumatické rány na kulturní krajině širokého pásu pohraničí. a dále "soumrak tradičního venkova" (Petráň, 2009: 481), na jehož průběhu se podepsala jak kolektivizace v padesátých letech 20. století, tak hospodářsko-politický vývoj následujících desetiletí. Rovněž část vnitrozemí České republiky je tak $v$ současnosti poseta lokalitami, které mají charakter vnitřní periferie. Citelně zde schází malé vesnické školy, které by formovaly zodpovědný vztah k rodnému místu již od dětství. Opuštěné kostely se otevírají návštěvníkům pouze výjimečně. Vedle

${ }^{22}$ Srovnej např́klad platforma Collective Responsibility, dostupné $\mathrm{z}$ www.collectiveresposibility.org. 
mizení symbolů tradičního venkova pak $\mathrm{v}$ posledních letech dochází rovněž $\mathrm{k}$ nečekaně rychlému "soumraku" tradičního regionálního průmyslu (Foltýn - Havlůjová 2012a: 166).

Obnova zodpovědného vztahu k místu a komunitě tak patří v současné době mezi zvlášt́ silně pocitóvanou společenskou potřebu, která rezonuje především tam, kde byl v uplynulých desetiletích přirozený vztah ke kulturně historickému dědictví uměle narušen či násilně zpřetrhán (Foltýn - Havlůjová 2012a, Märc - Lencová 2012). Zde všude se však zároveň otevírá široký prostor pro působení škol a citlivé využívání regionálního kulturně historického dědictví ku prospěchu žáků i místních komunit (Havlůjová 2012b, Hlaváček Funke 2012, Novák 2012, Prchalová - Šindeláŕ 2012, Matějka 2010).

\section{Seznam použité literatury}

- ASHWORTH, Graham J,, Graham, B., \& Tunbridge, J. E. (2000). A Geography of heritage: Power, culture and economy. London: Arnold.

- Trust, A. (2004). Opening doors: Learning in the historic environment. London: Attingham Trust.

- Brom, Z., Šmídová, D., \& Velková, Jitka., (2008) Ve Štorchovách stopách. In Parkan, František a kol (Ed.), Výchova ke vztahu ke kulturně historickému dědictví. Metodická př́ručka (pp. 118-128). Praha: Univerzita Karlova v Praze, Pedagogická fakulta.

- Carter, J. (2004). Interpretace místního dědictví, príručka pro plánování a tvorbu prezentací místních zajímavostí. Brno: Nadace Partnerství.

- Clark, Delia et al., (2008) Learning to make choices for the future. In Learning to make choices for the future. Connecting public lands, school, and communities through place-based learning and civic engagement. Retrieved from http://promiseofplace.org/curriculum and planning/planning tools

- Clark, K. (2001) From regulation to participation: Cultural heritage, sustainable development and citizenship. In Forward planning: The Function of cultural heritage in a changing Europe (pp. 103-112). Strasbourg: Council of Europe.

- $\quad$ Copeland, T. (1993). Geography and the historic environment. London: EH.

- Copeland, T. (2006). European democratic citizenship, heritage education and identity. Strasbourg: Council of Europe.

- Copelnad, T. (1991). Maths and the historic environment. London: English Heritage (EH).

- CČinčera, J. (2007). Environmentální výchova. Od cílů k prostředkům. Brno: Paido.

- Daňková, L., Kulich, J., \& Toušková, Blanka., (2009). Škola pro život II. Jak na ekologickou/environmentální výchovu po zavedení Rámcových vzdělávacích programů. Praha: Sdružení středisek ekologické výchovy Pavučina.

- Troyer, DE, , \& Veerle a kol, (2005). Heritage in the classroom. A Practical manual for teachers. Antwerp, Apeldoorn: Garant.

- Durbin, G., Morris, S., \& Wilkinson, S. (1990). A Teacher's guide to learning from objects. London: $\mathrm{EH}$.

- Fairclough, G. (2008) New heritage, an introductory essay - People, landscape and change. In G. Fairclough, R. Harrison, J. H. Jameson, \& J. Schofield (Eds.), The Heritage reader (pp. 297-312). Abington: Routledge.

- Fiedlerová, L., Najbertová, A., \& Svátková, B. (2011). Cesta za poznáním města. Brno. 
- FOLTÝN, Dušan a kol, (2008). Prameny paměti. Sedm kapitol o kulturně historickém dědictví pro potreby výchovné praxe. Praha: Univerzita Karlova v Praze, Pedagogická fakulta, Katedra dějin a didaktiky dějepisu.

- Kulturní dědictví a udržitelný rozvoj místních komunit. Cultural heritage and sustainable development of local communities (2012). Praha: Brontosauř́ ekocentrum Zelený klub.

- Cultural heritage and sustainable development: Eight case studies from Czech schools (2012). Praha: Brontosaurí ekocentrum Zelený klub.

- Havlůjová, H. (2008) Kulturně historické dědictví ve vzdělávací praxi. In Parkan, František a kol (Ed.), Výchova ke vztahu ke kulturně historickému dědictví. Metodická príručka (pp. 1438). Praha: Univerzita Karlova v Praze, Pedagogická fakulta.

- HavlŮjovÁ, H. (2012) Kulturně historické dědictví, výchova a koncept udržitelnosti. In D. Foltýn \& H. Havlůjová (Eds.), Kulturní dědictví a udržitelný rozvoj místních komunit. Cultural Heritage and Sustainable Development of Local Communities (pp. 10-27). Praha: Brontosaurí ekocentrum Zelený klub.

- HavlŮjovÁ, H. Silný hlas ticha aneb genius loci (v) paměti.. In J. Märc \& Lencová, H. a kol. (Eds.), Brána školního dějepisu otevřená. Možnosti výuky mimo školu, Acta Universitatis Purkynianae Facultatis Philosophicae - Studia Historica Didactica 4 (pp. 134-153). .

- Kulturní dědictví a udržitelný rozvoj místních komunit ve školní praxi. Metodická doporučení a príklady dobré praxe pro učitele základních a středních škol (2012). Praha: Brontosaurí ekocentrum Zelený klub.

- Hederer, J. (1994). Životní prostredí a výchova. Praha: Portál.

- HlavÁČek, T., \& Funke, M. (2012) Záchrana drobných sakrálních památek na Úštěcku. In D. Foltýn \& H. Havlůjová (Eds.), Kulturní dědictví a udržitelný rozvoj místních komunit. Cultural heritage and sustainable development of local communities (pp. 142-149). Praha: Brontosaurí ekocentrum Zelený klub.

- Holden, J. (2006). Cultural value and the crisis of legitimacy: Why culture needs a democratic mandate. London: Demos.

- Horká, H. (2005). Ekologická dimenze výchovy a vzdělávání ve škole 21. století. Brno: Masarykova univerzita.

- HUŠKOVÁ, Blažena a kol., (2010). Učíme se dobře rozhodovat pro budoucnost. Budování vztahů mezi školami, obcemi a správci veřejných pozemků a prostor cestou místně zakotveného učení a zapojování občanů. Brno: Horní Maršov: Středisko ekologické výchovy SEVER a Partnerství, o. p. s..

- Charvátová, K. (2009) Výchova ke vztahu ke kulturně historickému dědictví. In M. Gašparová \& Ligas, Š. (Eds.), Odkaz kultúrneho dedičstva v primárné edukácii (pp. 87-90). Banská Bystrica: Univerzita Mateja Bela v Banské Bystrici.

- Kindlmannová, J., \& Vošahlíková, T. (2010). Podpora vzdělávání k udržitelnému rozvoji [online]. $\quad$ Retrieved from http://www.vuppraha.cz/wpcontent/uploads/2010/02/Studie podpora VUR final.pdf

- Kratochvílová, J. (2009). Teorie a praxe projektové výuky. Brno: Masarykova univerzita v Brně, Pedagogická fakulta.

- KREBS, Vojtěch a kol, (2005). Formulace doporučení Ministerstva práce a sociálních věcí v oblasti udržitelného rozvoje vycházejících z mezinárodní komparace [online]. . Retrieved from http://www.mpsv.cz/files/clanky/2902/Zaverecna zprava 2005.pdf

- $\quad$ Langer, J., Šmíra, P., \& Bryol, R. (2011). Beskydy. Stavby a život v nich. Třinec: Wart.

- Lauermann, M. (2010) Standardy kvality komunitní školy. In Komunitní škola [online]. . Retrieved from http://komunitniskola.blogspot.com/2010/02/standardy-kvality-komunitniskoly.html 
- Máchal, A. (2000). Praktická ekologická výchova. Brno: Rezekvítek.

- MÄrc, J., \& Lencová, Hana a kol, (2012) Brána školního dějepisu otevřená. In Možnosti výuky mimo školu, Acta Universitatis Purkynianae Facultatis Philosophicae - Studia Historica Didactica 4. .

- Tragická místa paměti. Průvodce po historii jednoho regionu / Tragische Erinnerungsorte: Ein Führer durch die Geschichte einer Region 1938-1945 (2010). Praha.

- Partnerství, N. (2012). Komunitní rozvoj [online]. . Retrieved from http://www.nadacepartnerstvi.cz/vzdelavani/o-metodach

- Novák, V. (2012) Mezi pražci mladějovské úzkokolejky (2007-2010). In D. Foltýn \& H. Havlůjová (Eds.), Kulturní dědictví a udržitelný rozvoj místních komunit. Cultural heritage and sustainable development of local communities (pp. 120-133). Praha: Brontosaurí ekocentrum Zelený klub.

- Novák, V., \& Sýkora, P. (2008) Mezi pražci mladějovské úzkokolejky. In Parkan, František a kol (Ed.), Výchova ke vztahu ke kulturně historickému dědictví. Metodická príručka (pp. 95107). Praha: Univerzita Karlova v Praze, Pedagogická fakulta.

- $\quad$ Palmer, J. A. (2003). Environmental education in the 21st Century. London; New York.

- PARKAN, František a kol, (2008). Výchova ke vztahu ke kulturně historickému dědictví. Metodická př́ručka. Praha: Univerzita Karlova v Praze, Pedagogická fakulta.

- Doporučené očekávané výstupy. Metodická podpora pro výuku prưřezových témat $v$ základních školách (2011). Praha: Výzkumný ústav pedagogický v Praze.

- Pastorová, M. (2011). Doporučené očekávané výstupy. Metodická podpora pro výuku prưrezových témat $v$ gymnáziích. Praha: Národní ústav pro vzdělávání.

- Petráň, J. (2009). Dvacáté století v Ouběnicích. Soumrak tradičního venkova. Praha: NLN.

- Pownall, J., \& Hutson, N. (1992). Science and the historic environment. London: EH.

- Prchalová, K., \& Šindeláŕ, Jiří., (2012) Cesta z města - Cesty za pověstí. In D. Foltýn \& H. Havlůjová (Eds.), Kulturní dědictví a udržitelný rozvoj místních komunit. Cultural heritage and sustainable development of local communities (pp. 134-141). Praha: Brontosaurí ekocentrum Zelený klub.

- Sobel, D. (2005). Place-Based Education: Connecting Classrooms \& Communities. Barrington: The Orion Society.

- Environmentální vzdělávání, výchova, osvěta - teorie a praxe: Výběrová bibliografie za rok 2000 (2000). Praha: Univerzita Karlova v Praze, Pedagogická fakulta.

- Středisko ekologické výchovy a etiky Rýchory (SEVER 2010), (2010). Škola pro udržitelný život - přehled realizovaných projektů [online]. . Retrieved from http://www.skolaprozivot.cz/publikace

- ŠILHÁNKOVÁ, Vladimíra a kol, (2010). Jak sledovat indikátory udržitelného rozvoje na místní úrovni?. Hradec Králové: Civitas per populi.

- ŠILHÁNKOVÁ, Vladimíra a kol, (2011). Indikátory udržitelného rozvoje pro města a obce. Hradec Králové: Civitas per populi.

- Tichý, F. (2008) Nebojte se projektů aneb Výchova ke vztahu ke kulturně historickému dědictví a možnosti výchovně vzdělávacích projektů. In Parkan, F. a kol. (Ed.), výchova ke vztahu ke kulturně historickému dědictví. Metodická príručka (pp. 67-79). Praha: Univerzita Karlova v Praze, Pedagogická fakulta.

- Tomková, A., Kašová, J., \& Dvořáková, M. (2009). Učíme v projektech. Praha: Portál. 
- Vaněk, P. (2012) Muchovice. Za krajinou a lidmi minulosti. In H. Havlůjová \& J. Lešnerová (Eds.), Kulturní dědictví a udržitelný rozvoj místních komunit ve školní praxi. Metodická doporučení a přiklady dobré praxe pro učitele základních a stredních škol (pp. 137-143). Praha: Brontosaurí ekocentrum Zelený klub.

- Veberová, J. (2012) Lesní rybníky. In H. Havlůjová \& J. Lešnerová (Eds.), Kulturní dědictví a udržitelný rozvoj místních komunit ve školní praxi. Metodická doporučení a príklady dobré praxe pro učitele základních a středních škol (pp. 171-186). Praha: Brontosauř́ ekocentrum Zelený klub.

- Vošahlíková, T. (2011). Základy vzdělávání pro udržitelný rozvoj, Metodický portál: Články [online]. . Retrieved from http://clanky.rvp.cz/clanek/o/z/12983/ZAKLADY-VZDELAVANIPRO-UDRZITELNY-ROZVOJ.html/

- Vzdělávání pro udržitelný rozvoj (VUR 2011) Vzdělávání pro udržitelný rozvoj. Opatření pro roky 2011 a 2012 ke Strategii vzdělávání pro udržitelný rozvoj České republiky (2008-2015). Opatření vlády ČR, č. j. 1266/10. . .

- ZahradnÍkovÁ, J. (2008) Průřezové téma Výchova ke vztahu ke kulturně historickému dědictví. In Parkan, F. a kol. (Ed.), Výchova ke vztahu ke kulturně historickému dědictví. Metodická príručka (pp. 8-11). Praha: Univerzita Karlova v Praze, Pedagogická fakulta.

PhDr. Hana Havlůjová, Ph.D., zabývá se dějinami české moderní společnosti, didaktikou dějepisu a otázkami interpretace kulturně historického dědictví, působí na Katedře dějin a didaktiky dějepisu Pedagogické fakulty UK v Praze, hana.havlujova@pedf.cuni.cz

Mgr. Dušan Foltýn, jako pracovník Centra medievistických studií AV ČR se dlouhodobě věnuje výzkumu dějin českých řeholních institucí, v rámci pưsobení na Katedře dějin a didaktiky dějepisu Pedagogické fakulty UK v Praze je garantem výuky historické regionalistiky, dusan.foltyn@pedf.cuni.cz

Prof. PhDr. Kateřina Charvátová, CSc., zabývá se středověkými dějinami, v posledních letech též otázkou kulturně historického dědictví a jeho využití ve vzdělávací praxi. Pracuje na Katedře dějin a didaktiky dějepisu Pedagogické fakulty UK v Praze, katerina.charvatova@pedf.cuni.cz 
Časopis Envigogika vydává Centrum pro otázky životního prostředí UK. Vývoj časopisu je podpořen projektem OP VK Mezioborová sít udržitelného rozvoje.

Více najdete na internetových stránkách projektu http://mosur.czp.cuni.cz
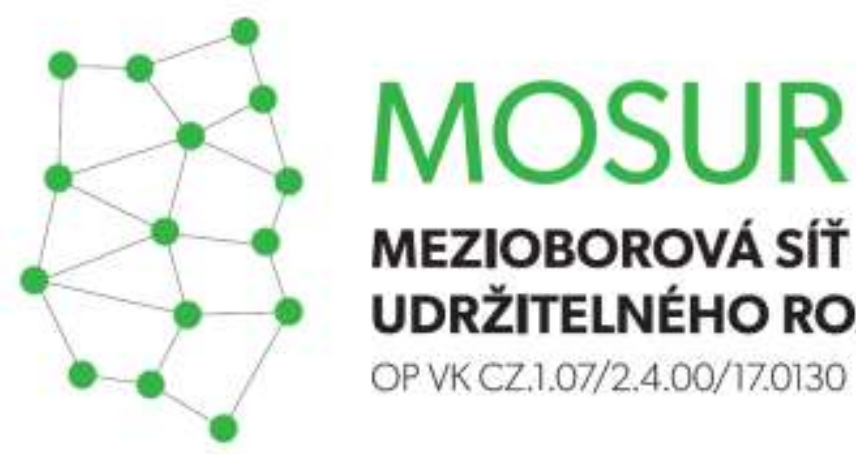

\section{MEZIOBOROVÁ SÍT}

UDRŽITELNÉHO ROZVOJE

OP VK CZ.1.07/2.4.00/17.0130
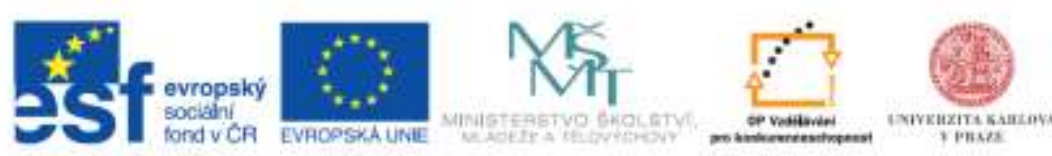

INVESTICE DO ROZVOJE VZDELAVANI 